\title{
How Significant was the Iberian Jewish Contribution to Technology and Economic Life in the Ottoman Empire?
}

\author{
Benjamin Braude *
}

The role of Iberia's Jews in the Ottoman Empire has been much exaggerated and misunderstood. Even a work as well-respected and influential as Braudel's La Mediterranee... abounds in unjustified claims. For instance, he uncritically repeats the statement attributed to the Venetian diplomat Soranzo, speaking against a proposal before the council of ten in 1573 , to expel the Jews,

"What pernicious act in this to expel the Jews? Do you not know what it may cost you in years to come? Who gave the Turk his strength and where else would he have found the skilled craftsmen to make the cannon, bows, shot, swords, shields and bucklers which enable him to measure himself against other powers, if not among the Jews who were expelled by the Kings of Spain?" '.

Of course Braudel did have reason to accept such statements. He took Soranzo's words from the translation of a Hebrew chronicle; furthermore the notion of a Jewish contribution to Ottoman military might was confirmed by another slightly earlier source the Navigations of Nicolas de Nicolay, of whom more later ${ }^{2}$.

* Universidad Hebrea de Jerusalén.

BAAUDEL, Fernand, The Mediterranean and the Mediterranean world in the age of Philip II, Sian Reynolds (tr.), II. New York 1976, págs. 808-809, and English tr. of Joseph Hacochen \& The Anonymous Corrector, The Vale of Tears, Harry S. May (tr.). The Hague 1971, pág. 115.

2 Navigations of NiCOLAY, Nicolas de, first published in Lyons in 1567 and translated into numerous languages, including Italian, Germand, and Dutch, published in dozens of editions and printings, the English tr. (London 1585) on pág. 130 reads as follows: 
Another example of Braudel's uncritical approach is the following:

In the Levant, contemporary accounts all agree on the major role played by the Jewish merchants; they controlled the markets at Aleppo and (particularly Portuguese Jews) in Cairo, as moneylenders to whom the Christians often had recourse and in whose hands the ENTIRE [MY EMPHASIS] caravan trade was clearly concentrated ${ }^{3}$.

Quite apart from the meandering syntax, the statement that the entire caravan trade of Cairo was in their hands is not confirmed by any reliable source.

Thus a variety of accounts have served to support the idea that Iberian Jews played the preeminent, even dominani, role in the economic and technological development of the Ottoman empire during the sixteenth century. The multiplication of errors in these sources is so multi-layered that it is sometimes very difficult to disentangle the strata of truth from the much more numerous strata of falsehood. The contemporary accounts to which Braudel referred were certainly not the records of the Ottoman archives or other local Islamic or Jewish sources nor were they even archival records of the Europeans involved in trade. By and large Braudel and, for that matter, many other less distinguished historians, have relied, directly and indirectly, on a variety of inadequately understood and carelessly used stories written by European travellers. Few were professional merchants. Most were adventurers and tellers of tall tales whose success depended to a great degree on their ability to appeal to the prejudices and credulity of their European Christian audiences. Even those whose detailed and precise observations as well as lack of sales demonstrate the seriousness of their accounts could not completely escape the bias of their age.

\footnotetext{
"Likewise they have amongst them workmen of all arts and handicrafts most excellent, and especially of the Marranos of late banished and driven out of Spain and Portugal, who to the great detriment and damage of the [sic] Christianity, have taught the Turks divers inventions, crafts, and engines of war, as to make artillery, harquebuses, gunpowder, shot, and other munitions...".
}

Nicolas goes on to claim that Ottoman Jews not only established printing presses in Hebrew but also for Greek, Latin, Italian and Spanish! There is no evidence that at this point Jews printed anything but Hebrew. The first Greek book to bear an Ottoman imprint was Syntomos Pragmateia kata ton loudaion printed in 1627. Although the book's title page claimed that it was printed in Constantinople, in fact it was actually set in London by a Greek printer who then traveled to the Ottoman Empire with the press on board a ship of the Levant Company. In response to Jewish and European diplomatic protests, the book and press were suppressed by the Ottoman authorities almost immediately.

3 Braudel, II, pág. 819. 
The nature of the bias is in fact far more complex than one might first imagine. Of course Jewish historians are quick to recognize the abundant anti-Jewish sentiments prevalent in such Christian sources. For instance Pierre Belon, an astute observer who is one of Braudel's principal sources, claimed in his 1554 book of observations about "plusieurs singularitez et choses memorables" etc... that

The Jews wherever they are, are more crafty than any other nation. They have so completely seized hold of all the trade in merchandise in Turkey that the riches and revenue of the Turk are in their hands... Since I have many times been obliged to used the services of the Jews and to frequent them, I have readily learnt that this nation is the most subtle and the most full of malice ${ }^{4}$.

Moreover Nicolas de Nicolay immediately places next to his account of Jewish contributions to Turkish military technology the charge that the Jews are cfull of all malice, fraude, deceit, and subtle dealing, exercising execrebale usuries amongst the Christians and other nations without any consciences or reprehensión...". He then reminds his readers of their stubborness in refusing to acknowledge "the brightness and light of lesus Christ" whom they "condemned and caused to die on the cross" ${ }^{5}$.

However most scholars have refused to recognize the distorting effects of such prejudice and furthermore failed to realize that this in only one of at least three forms of bias all of which play a role in undermining the reliability of these accounts. In addition to the manifest fear and loathing of the Jews, most contemporary European writers on the East also harbored (2) fear and loathing of Spain and (3) fear and loathing of the Ottoman Empire. Note the significant fact that so-called anti-semitism is not alone sufficient to explain the portrait we have from the contemporary European travel accounts upon which Braudel and many others have based their claims of Jewish economic dominance.

The bias against the Ottomans is hardly surprising, but that against Spain is. To understand it I rely upon the research of Prof. Jocelyn Hillgarth on the image of Spain in early modern Europe. Prof. Hillgarth of the Pontifical Institute for Mediaeval Studies at the University of Toronto, is my colleague for the year at the Institute for Advanced Studies at the Hebrew

4 BELON, Pierre, Les observations de plusieurs singularitez et choses memorables trouvées en Grece, Asie, Judee, Egypte, Arabie et autres pays étranges, 1st ed. Paris 1553, 181 recto verso.

5 English translation. London 1585, pág. 131. 
University, where he is part of a research group studying the Jewish world after 1492. According to him, for most European Catholics and Protestants alike, Spaniards and for that matter Portuguese as well were hardly to be distinguished from the Moors, Marranos, and other infidels in their midst. That the inquisition was designed to extirpate heresy from the bosom of Iberia merely proved how deep-rooted it was. It was a commonplace among contemporary European observers that many, if not most Iberians, were secretly Jews or Muslims, or both, since one variety of infidelity was hardly worth distinguishing from another. Heresy and religious infidelity were simply national traits of the Spaniards that were taken for granted along with garlic breath and other distasteful personal habits. Obviously envy of Spain's wealth and power made the French, Dutch, Italians, English and others tar the Spaniards with whatever handy brush of accusation they could find.

Fear and loathing of the Turk as horrific infidel invader is understandable. But coupled with the recognition of the awesome military might of this Muslim adversary was a reluctance to acknowledge that the Turk was himself capable of inventing and producing anything of value on his own. It was more reassuring to imagine that whatever skill the Turk had, originated not with him, but with a renegade or exile from Europe. By denigrating the ability of the enemy, Europeans made him seem less frightening and more manageable. Incidentally this was an old technique in the Christian understanding of Islam, Mohammed was not really an Arab pagan, according to the popular polemics of medieval Christendom but a one-time Cardinal and failed candidate for the papacy, who, out of spite at his defeat, exacted vengeance upon his fellow-Christians by running off to the desert and raising this fearful heresy. Furthermore to believe that Turkish success might be derived from their own creative abilities which might conceivably be divinely-inspired would contradict the belief that Christians and Christians alone are favored by God. If some Jews and renegades chose to aid the enemy by furnishing him with the secret techniques of Europe that is their evil not God's will.

Thus the TOPOS that the Jews expelled from Spain provided the Turks with the military know-how to defeat the Christians was a wonderful stick with which to beat everybody. It denigrated the Turks. It revealed the perfidy and evil of the Jews. It accused the Spaniards of creating the instrument of their own and Europe's --heaven forefend- destruction, thereby revealing that Spain, far from being the bulwark of Christendom as it ceaselessly and fervently proclaimed - to the annoyance of most other Christians - was in fact directly responsible for the most serious challenge which Christianity had ever faced. Ultimately it was also a source of hope, for if the technical means of Turkish victory were simply stolen from Eu- 
rope, then surely, ultimately, Europe had within it the wherewithal to invent even better military techniques to restore the balance to what it should be. Even Jewish writers, who should have known better, picked this TOPOS up and used it for their own apologetic purposes in opposing attempts to expel them.

The other related TOPOS, that the Jews have seized hold of all the trade, riches, and revenue of the Turks did not serve quite as neat a polemical purpose as the first. But, like the first, it also reveals more about the experience and assumptions of the creators and consumers of this particular commonplace than it does about the society supposedly described.

As in the first TOPOS, the second also reveals a reluctance on the part of the European to recognize the ability of the Turk in any sphere whatsoever and an eagerness as well to attribute whatever economic wealth his empire has attained to some external, preferably European-connected, source. An analogy to this has existed in art history wherein there has been a well-established tendency current over the past century, but now no longer respectable, to attribute much of the aesthetic creativity of Ottoman art to Persian and other foreign influences. Although the Persians were not Europeans, they were speakers of an Indo-European language, and strategically were allied from time to time with Europe against the Turks. Thus they were a much less threatening and alien force in the European imagination. Recent events may make that historic image now seem incredible, but such was the case in the past.

Since in economic terms the Turkish anti-Christ was incompetent, what better notion than to have the Jews, the very embodiment of the deicidal impulse, portrayed as their helpmates who do the work for them to the point of taking over. Although these images of Turkish technological incompetence coupled with Jewish economic dominance clearly suited the mythic religious predisposition of Europe, they were not complete fabrications. In a dim, distorted and incomplete way they did reflect a reality. The idea that some Jewish refugees from the Western Mediterranean contributed to Ottoman technological development is true, but the technology was not military. The idea that Jews played a dominant role in Ottoman commerce did reflect the straitened and limited experiences of most travellers as well as the Eurocentric economic assumptions of most merchants.

\section{LET US TURN TO THE FIRST OF THESE DISTORTED IMAGES}

What about military technology? Is there any basis for these claims? A close examination reveals their absurdity. If in fact lberian and other 
Jews forced out of the Western Mediterranean at the end of the fifteenth century and shortly thereafter were the source of Ottoman superiority, how had the Ottomans managed in the earlier course of the fifteenth century, before the arrival of these Jews, to conquer Constantinople, to destroy the last vestiges of Christian rule in Anatolia and the Balkans, as well as to invade Italy and threaten the existence of Christendom? Mehmet the Conqueror and his father Murad II seemed to have done very well without any Iberian Jewish assitance whatsoever. Furthermore there is no evidence from western Mediterranean sources that Iberian Jews had any special expertise in military technology. Did Jewish peddlers and tailors miraculously undergo job retraining as canon founders and bow crafters on the creaky ships and dusty roads they took to seek their Ottoman refuge?

However there was a technologically innovative industry which the Jews did introduce to the Ottoman Empire and which from its foundation was connected to the elite of the Ottoman military, the Janissary corps. Although connected to the military, it was not itself a military technology. The industry in question was the woolen textiles industry founded in Salonica by the first decade of the sixteenth century. Its connection to the military lay in the fact that its principal customer was the Janissary corps which clothed its troops with Salonica woolens. Its innovative technology imported from the West was the use of water-powered mills with which to full or finish the cloth. The process of fulling made the cloth stronger, more impermeable to rain and snow, precisely the qualities needed for the Ottoman military in their thrusts northward into the heartlands of Europe. The mechanical fulling mill replaced the older and more expensive process of fulling by hand-held club or by foot, reducing the cost of the cloth by a significant degree. While this was hardly a cannon or an harquebus, it did represent a technological advance of use to the military. Furthermore the industry was well-known to European observers. It is reasonable to suppose that this industry furnished the excuse for the belief that Spanish Jews were building technologically innovative weapons for the Ottoman army.

As for the common European belief that Jews dominated the Ottoman economy, this too had some basis in the limited reality experienced by the European living under the Turk. Given the linguistic isolation of both the East and the West, Europeans in the Ottoman empire were dependent on go-betweens, dragomans, guides, fixers, middlemen, call them what you will, to get things done. The nature, read self-interest, of such intermediaries is to exaggerate their own importance in a complex process for which they were, at best, lubricants for the cogs of the wheels of power. Furthermore it was also in the nature of the Europeans themselves to claim a closer proximity to power than was the case. Thus a kind of silent con- 
spiracy caused the dragoman to become the pasha. Since in the sixteenth century Jews were one of the few groups in the Empire who had the minimal cultural and linguistic skills needed to mediate, at the modest practical level required, between the European visitors and the Ottoman authorities, for many foreigners the Jew became the pasha.

The misimpression of Jewish economic dominance that European observers drew on the basis of their own limited experience reflected not only prejudice against Ottoman competence and the self-serving psychology of the client-middleman relationship, but also a distorted geoeconomic view of Ottoman commercial activity in general. Europeans naturally assumed that Ottoman trade with Europe was the most important foreign trade of the Empire. In point of fact the Ottomans also maintained very important direct trade ties with Africa, the Indian subcontinent, the Indonesian archipelago, the Muslim khanates of central Asia, as well as Iran, and through these partners, China. The nature of this trade was very largely in expensive items of luxury, such as jewels, silks, spices, and other precious commodities. Although Europe provided woolen cloth, a bulky commodity, and was one of the sources of slaves, an even more bulky commodity, few of Europe's products matched the value of what came exclusively from the south and east. In the absence of comprehensive, detailed and reliable trade figures for the Ottoman Empire in the sixteenth century it is impossible to give a quantifiably certain calculation of the relative importance of European versus African-Asian trade, but it is reasonable to suppose that Europe was certainly not more important than the other trading area and in all likelihood was probably less important. Furthermore in qualitative terms the Ottomans clearly valued contacts with Europe less highly. The Muslim world, whose leadership the Ottomans aspired to command, particularly after the conquest of the Twin Shrine Cities of Mecca and Medina in 1517, lay to the east and south of the empire. Trade with these areas was overwhelmingly in Muslim hands, for the maintenance of contacts with lands of Islam was an intimate part of the cultural and political life, indeed the evolving raison d'etre, of the Ottoman empire. The pilgrimage to Mecca, which was crucial to the creation of the world of Islam, was also an important vehicle for the maintenance of international trading contacts - such contacts were by definition exclusively in Muslim hands.

Although in the time of the Fatimid empire (roughly 10th through 12th centuries) - what after Goitein may be called the Geniza age-Jews played and important role in the trade through Arabia with India and points further East, there is no evidence that this presence continued to the same extent in subsequent centuries. In fact there is significant evidence to the contrary, witness the establishment of the Jewish trading colony in Kaifeng, 
China during roughly the Geniza period and its isolation from the rest of the Jewish world by the sixteenth century, when Matteo Ricci and his fellow Jesuits met them - an indication that Jews were unable to maintain an ongoing presence in East Asia much past the century of Mongol expansion.

Thus by the sixteenth century it is clear that Jews played little role in the trade which was probably the major area of concern for the Ottomans, that to the east. To the extent that Jews had a role in Ottoman commerce, it was in the secondary market, the trade with Europe. Where and precisely how significant that role was, are questions which cannot be answered on the basis of the reports of European travellers alone.

Unfortunately even for Venice, that most well-documented of Turkey's western trading partners, we lack the kind of hard quantitative evidence that will furnish a definitive answer. Some thirty years ago, Bernard Blumenkranz argued on the basis of a small and perhaps unrepresentative sample that the Jewish role in Venetian-Ottoman trade had been much exaggerated ${ }^{6}$. More recently Benjamin Arbel has pointed to the weaknesses in Blumenkranz's evidence and, drawing upon a wider range of sources, has suggested that, at least as far as trade between Venice and Istanbul was concerned during the mid-sixteenth century, Jews played a very important role ${ }^{7}$. However Arbel cannot put a precise figure to this claim. He, among others, does point to the fact that Venice and other Italian states gradually proceeded in the course of the sixteenth century, against significant internal opposition in many instances, to take the hard and practical step of issuing invitations to Iberian exiles to seek refuge in their realms in order to facilitate trade in general and with the Ottoman Empire in particular. Whether or not the Jews actually played a dominant role in the Ottoman economy, many Italians believed they did and this was good enough for them, whatever the reality.

As usual the reality was a good deal more complicated. Although in general we lack the quantitative data necessary to assess precisely the Jewish role, we do have certain exceptions which are worth exploring. The two examples I present are both drawn from unpublished research based, respectively, on Ottoman documents and the archives of the Levant Company.

6 "Les juifs dans le commerce maritime de Venise (1592-1609) a propos d'un livre recent", Revue des Etudes Juives, 3rd srie, 1961, págs. 143-151.

7 "Venice and the Jewish merchants of Istanbul", The Mediterranean and the Jews, ed. A. Toaff and S. Schwarzfuchs, Bar-llan University Press. Ramat-Gan 1989, págs. 39-56. 
The Ottoman documents cover a longer period and thus allow a more confident judgment of their validity. However they deal with a somewhat peripheral location, Ottoman-ruled Buda (modern Budapest) and thus their wider representativeness may be questioned. The English documents cover a much shorter span of time, but deal with the very center of the Empire, the capital, Constantinople.

For Ottoman Buda we have several customs registers dating from the second half of the sixteenth century ${ }^{8}$. The one most carefully examined is from 19 November 1550 to 6 May 1551, within the period described as dominated by Jews. According to Muslim law, the religious identity of the merchant appears on the register - hardly surprising for religion determined rate of duty. Since we have only first names, it is impossible to identify the ethnic origin of these Jews, Iberian or otherwise, but given the date, well after the main influx of the exiles, it is reasonable to assume that Sefari Jews were represented in this trade. Of the 369 merchant entries $68 \%$ were Muslim, $26 \%$ were Christian and only $6 \%$ were Jewish. The register also allows us to analyze the totals by type of commodity. Of the 148 entries for foodstuffs, $97 \%$ Muslim, $1 \%$ Christian, $2 \%$ Jewish. Of the 80 entries for cloth and apparel, $70 \%$ Muslim, $23 \%$ Christian and $7 \%$ Jewish. Of the 67 entries for animal hair and skins $54 \%$ Muslim, $44 \%$ Christian and $2 \%$ Jewish. Of the 40 entries I have dubbed miscellaneous, including wax, livestock, tools, weapons, saddles, and slaves, $98 \%$ Muslim, $2 \%$ Christian and no Jewish participation whatsoever. Of the 34 entries for wine, a prohibited commodity for Muslims, $92 \%$ Christian and $8 \%$ Jewish, the highest percentage, but also the lowest sample of any single commodity. I have examined lated Buda customs registers for the year 1571-72, 1572, 1573, 1573-74, and 1579-80 with similar results: the Jewish role was modest to insignificant. A study based on the customs registers for the northern Hungarian town of Vac in the 1560 s confirms that there too the Jewish role was negligible ${ }^{9}$. In the face of this Ottoman evidence from Hungary, Belon and Nicolay's sweeping claims cannot be maintained. Of course it is possible that there was massive smuggling, or instances of Jews trading with a Muslim cover to gain lower duty. Obviously such evasion of the law would distort the figures, but there is no reason to believe that such practices existed on a wide enough scale to impeach this evidence completely.

\& FEKETE, Lajos and KALdY-N AGY, Gyula, Regnungsbucher des osmamischen Buda. Budapest 1962.

9 Vass, E., «Türkische Beiträge zur Handelsgeschichte der Stadt Vác (Waitzen) aus dem 16. Jahrhundert”, Acta Orientalia (Academia Scientiarum Hungarica), n. ${ }^{\circ} 24,1971$, págs. 1-39. 
On the other hand evidence that we have from Istanbul in the 1620 s seems, at first sight, to confirm the claims of Sefardi Jewish economic dominance. Unfortunately it is not an Ottoman customs registers - such documents apparently have not survived for the capital- but rather an English notarial record of all the contracts registered with the embassy for the period January 1622 to May $1625^{10}$. Typically these were agreements between English merchants who were members of the Levant company, and local merchants. Of the 270 local merchant entries, $91 \%$ were Jewish, a remarkable indication of the dominance that Jews were able to obtain in this particular sector. Since in this instance we have the complete names of almost all the merchants involved, here we can identify the ethnic origins of at least some of them. Sefardi names such as Abravanello, Almeda, Alfasi, Alguedis, Alkalai, Arroches, Baroccos, Chalfon, Cordero, Cordova, d'Alva, Di Leon, di Hueglios, Ergas, ibn Habib, Rosales abound. However many of the other names could very easily be of non-Sefardi origin. And the single most common entry of all was Ashkenazi!

This finding is clear evidence of Jewish, if no necessarily Sefardi, dominance of at least one sector, indeed a growing and important sector of international tradee in the Ottoman capital during the 1620s. However there is a distinction to be made between this specific and supported assertion and the sweeping generalizations which I challenged at the outset of my talk. We cannot say how long this dominance continued. Our records stop during the first half of 1625 . Moreover should the first half statistics of 1625 at all representative of a longer trend, then the marked decline of that early part of the year might indicate a change for the worst in Jewish fortunes.

Although we lack comparable evidence for the next decade we do have a very important and closely related souce which might set these bits of evidence in a wider context. The Merchants Mappe of Commerce; wherein the Vniversell Manner and Matter of Trade is compendiously handled, a practical treatise on international trade was published in London in 1638, making it one of the earliest such works. The distinction it garnered insured that it was reprinted at least twice. Its author, Lewis Roberts, was both an experienced merchant in the Ottoman empire -indeed his name appears in the very notarial records of the Levant Company just cited- and one of the pioneers in the study of foreign commerce. In 1617, at the age of 21, he entered the service of the East India Company and later the Levant Company and remained continuously active in the pursuit and study of

10 Public Record Office. London, State Papers 105/102. 
trade until his death in 1640 . His family connections mirrored this interest. His wife was the daughter of a cloth merchant. His eldest son became a high official of the Africa Company and his eldest daughter married an English merchant in the Levant. This was not an ill-informed traveller eager to regale an audience with sensational half-truths from the lands of the infidel. Clearly he was a man whoo lived and breathed England's trade with the East. Thus his judgements deserve attention not only because of his knowledge and experience but also because of the respect that his work continued to command for decades after his death. Unfortunately, despite its value, the book is now neglected by students of Mediterranean commerce.

Roberts devotes a section to "the trade of the citizens of Constantinople» which is remarkable for the degree to which it is at variance with the implications of the notarial statistics ". Despite the apparent dominance by Jews of English trade in the capital during the early 1620s, a dominance with which we know Roberts was personally familiar, his account suggests that they were merely one of three major indigenous trading communities, but by no means the dominant in long-distance or international trade. Either the Jewish position in the English records was a temporary aberration or unrepresentative of their position in the market as a whole or both. The Merchants Mappe of Commerce lists them along with the Greeks, Turks, and Armenians. During the 1620 s and 1630s he describes them as principaly involved in internal trade to Edirne, Ankara, Salonica, and other cities in Greece. The Turks traded with Venice, Mecca, Damascus, and Cairo - the latter venus (I should add) which opened to the trading routes of Africa and greater Asia. The Armenians traded with the Caucausus and Iran -this was the century (I should add) which saw the rise of the Armenian city of New Julfa, sister city to the Safavid capital, Isfahan, established by Shah Abbas as an Armenian trading colony. As far as the Greeks of Istanbul were concerned, Roberts dismisses them as sailors and shopkeepers; they "cannot be tearmed Merchants".

What is also worth noting in Roberts' acount, along with the modest assessment of the Jewish economic role, is the marked absence of the virulent anti-Jewish vituperation which characterizes what we might dub the Jewish economic octopus school of Belon and Nicolay. Of course it may very well be that Robert's assessment merely reflects the decline of the Jewish role from the mid-16th to the early 17 th century and no more.

1 Chapter CCXLVII, págs. 198-199. Please note pagination is not continuous, both chapter and page number are necessary for precise reference. 
But I would argue that had he subscribed to that school he certainly had ready evidence in his own experience to make the claim. That he chose not to suggests that, among other implications, those who had made these claims in the past were often reflecting their own fears and paranoias more vividly than the reality they claimed to represent.

Now to summarize and answer the question raised by the title - How significant was the Iberian Jewish contribution to technology and economic life in the Ottoman Empire? Simply put, the claims for widespread dominance and major technological innovation are unfounded, so if that be the scale of comparison the contribution was insignificant, but if such claims are recognized as merely mythic projections of an impressive, if not astounding, reality, then the contribution is worthy of note. They did after all introduce new technology into the Ottoman textile industry, even though that industry could not ultimately resist the invasion of English cloth. They did after all introduce printing into the Ottoman Empire, even if it effectively remained an exclusively Hebrew industry. And they did play an important, but not dominant role, in the early development of Ottoman trade with the West. These are noteworthy achievements for a community forced out of their centuries-old home to seek refuge in a new and alien environment. 